\title{
Research on Pathogens at Great Lakes Beaches-Sampling, Influential Factors, and Potential Sources
}

The overall mission of this work is to provide science-based information and methods that will allow beach managers to more accurately make beach closure and advisory decisions, understand the sources and physical processes affecting beach contaminants, and understand how science-based information can be used to mitigate and restore beaches and protect the public.

The U.S. Geological Survey (USGS), in collaboration with many Federal, State, and local agencies and universities, has conducted research on beach health issues in the Great Lakes Region for more than a decade. The work consists of four science elements that align with the USGS Beach Health Initiative Mission: real-time assessments of water quality; coastal processes; pathogens and source tracking; and data analysis, interpretation, and communication. The ongoing or completed research for the pathogens and source tracking topic is described in this fact sheet.

\section{Pathogens at Great Lakes Beaches}

Beach advisories and closings, based on the fecal indicator bacteria (FIB) Escherichia coli (E. coli) and enterococci, are intended to protect the public from coming into contact with pathogenic (disease-causing) organisms. FIB are not necessarily pathogenic themselves, but they may indicate the presence of pathogenic organisms. The United States (U.S.) Centers for Disease Control and Prevention (CDC) report that between 1999 and 2008, four major pathogens were associated with outbreaks of illness acquired from ambient (as opposed to swimming pools) recreational water: the bacteria E. coli and Shigella, Cryptosporidium (protozoa), and norovirus (virus). In up to 21.9 percent of reported cases, the pathogen that caused the illness was not determined (Centers for Disease Control and Prevention, 2011). The bacteria Salmonella and Campylobacter, together with a few rarely occurring pathogens, accounted for fewer than 8 percent of cases. Methicillin-resistant Staphylococcus aureus (MRSA) have been detected at marine beaches. With the exception of MRSA, these pathogens typically cause gastrointestinal illness of varying severity, and enter recreational water through dissemination of human and animal wastes. MRSA are typically skin-associated, are reported to arise from swimmers themselves, and are of considerable concern because their resistance to antibiotic treatment leads to life-threatening infections. The USGS has conducted studies of pathogens at 12 representative Great Lakes beaches, in storm drains that deliver runoff to beaches, and in a focused study at Lake Michigan beaches.

\section{Developing New Methods to Test for Pathogens}

The FIB are used to indicate the possible presence of pathogens, but may not have the same survival properties as all pathogens. For example, FIB in the environment may not survive as long as pathogens, falsely indicating safety, or FIB may survive or grow longer than pathogens, falsely indicating risk. There have been only a few studies of pathogens at Great Lakes beaches, because each pathogen requires a separate test, and traditional methods require the organism in question to be cultured in the laboratory and confirmed with several tests. It would be costly and time consuming to routinely analyze for a large suite of pathogens, and even if none are detected for this analysis, there could be other pathogens present that were not part of the suite that were analyzed. However, new methods that rely on the detection of genes associated with specific pathogens are widely applied to food, and to clinical samples in hospitals, to determine the cause of illness. These methods include polymerase chain reaction (PCR) and quantitative PCR (qPCR), by which many thousands of copies of a signature gene for the pathogen can be created. The qPCR can be conducted in a few hours, and offers potential for more rapid determination of recreational water quality than growth-based methods, such as for the FIB, which typically take 18 to 24 hours to process. The USGS has developed and used both PCR and qPCR to detect or enumerate bacterial pathogens and viruses at Great Lakes beaches.

\section{Study of Twelve Representative Great Lakes Beaches}

The USGS conducted studies in 2010 to identify factors that influence bacterial pathogen and microbial source tracking (MST) genes at beaches, and relate pathogen and source-tracking gene occurrence to concentrations of $E$. coli and enterococci. In cooperation with multiple local partners, approximately 30 samples were collected over a range of environmental conditions from each of 12 beaches in Wisconsin, Michigan, Ohio, and New York, on Lakes Michigan, Huron, and Erie, and daily environmental data were recorded (fig. 1).

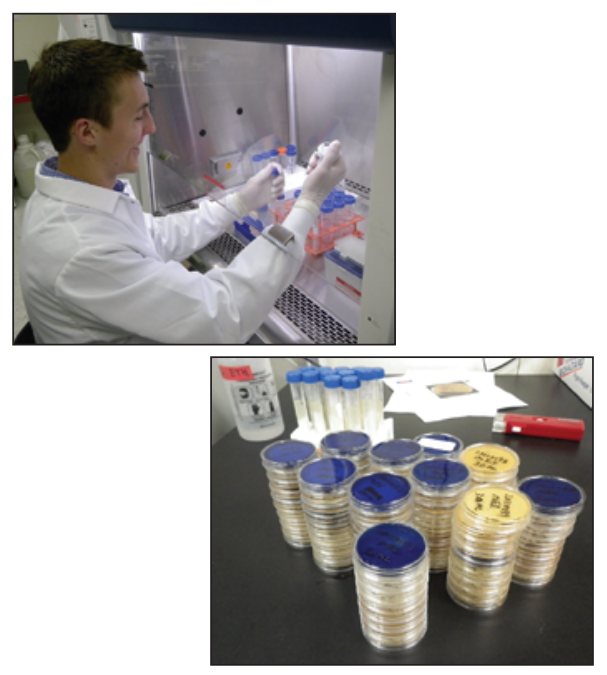

Figure 1. Over 300 samples from 12 representative Great Lakes beaches were tested for the presence of selected bacterial pathogens, by culture, combined with genetic methods. 
Land cover was determined for beach catchments and adjacent river watersheds using geographic information systems. The PCR was used to detect genes indicating the following bacteria: Shigella spp., pathogenic Salmonella spp., Shiga toxin-producing E. coli, Campylobacter jejuni and Campylobacter coli, and MRSA. Variables influencing frequency of occurrence of gene markers were determined using multiple statistical approaches. Although FIB concentrations and total pathogen count were significantly highest at beaches that exceeded any of several recreational water-quality criteria, pathogen genes still were detected in waters that met all criteria. Wave height and water velocity along the beach were important factors influencing FIB concentrations, as were various indicators of urban development, and runoff from rainfall events. Additionally, the qPCR was used to detect source-tracking markers in a subset of samples. No beach had only a single source identified, and the sources indicated changed by date, further emphasizing the complexity of beach indicator bacteria and pathogen dynamics. This study was the first to examine Staphylococcus aureus and the occurrence of MRSA at Great Lakes beaches. Likewise, this study was the first to evaluate the occurrence of pathogen genes in storm drain waters that flow into Great Lakes beaches. Study results should be available in several publications in 2013.

\section{Focused Study at Three Lake Michigan Beaches}

A subset of three Lake Michigan beaches was sampled using large-volume glass-wool filtration for the qPCR analysis of 22 waterborne pathogens including 8 human viruses, 8 bovine viruses, 4 bacteria, and Cryptosporidium parvum (fig. 2).

Bacterial pathogens analyzed were Campylobacter jejuni, Salmonella enterica, enterohemorrhagic E. coli and Mycobacterium avium subsp. paratuberculosis. These three beaches were chosen to represent a range of land uses in the surrounding watershed (rural, agricultural, and urban). A total of 71 samples were collected during summer 2010 at these three beaches. There was very highdetection frequency of human viruses and pathogenic bacteria, no detection of protozoa, and lower detection and concentration of bovine viruses than that of human viruses. All three beaches had detections of human and bovine viruses and pathogenic bacteria indicating the influence of multiple sources at these beaches. Human viruses and bacterial pathogens were present in a sufficient number of samples to explore results with statistical analysis using various measures of water quality, hydrology, and weather conditions to explain variability in pathogen concentrations. This included data from water samples collected concurrently with the pathogen samples as well as data retrieved from the USGS, NOAA, and the National Weather Service through the Environmental Data Discovery and Transformation (EnDDaT) system (http://cida.usgs.gov/enddat/). Data used in statistical analysis included E. coli, turbidity (measure of water clarity), specific conductance, rainfall, water and air temperature, water and wind velocity and direction, lake level, wave height and direction, and cloud cover. Variables found to have the greatest influence on human virus occurrence and concentrations were water temperature, wave direction, and air temperature. Variables found to have the greatest influence on bacterial pathogen concentrations included cloud cover, rainfall, wave direction, and wave height.

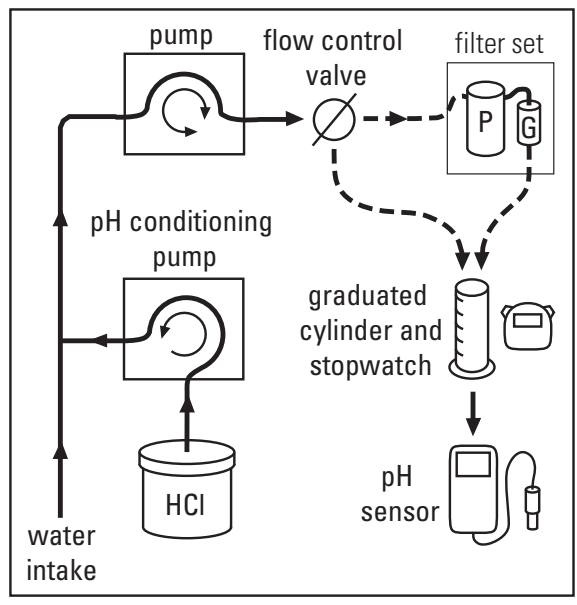

Figure 2. Large-volume glass-wool filtration system. Sample water is mixed with dilute hydrochloric acid to achieve an optimal and uniform $\mathrm{pH}$, then pumped to the filter set, which consists of a pre-filter $(\mathrm{P})$ and a glasswool filter $(G)$. The rate of flow is measured in the graduated cylinder, and $\mathrm{pH}$ is recorded throughout the sample duration.

\section{Application of qPCR to Bacterial Pathogens in Water, Sediment, and Algae at Great Lakes Beaches}

Previous research has shown that beach sediment, and the nuisance alga Cladophora, may harbor bacterial pathogens. A focused study was designed to evaluate the quantities of genes indicating typical bacterial pathogens in these matrixes, and in water from the same beach. The qPCR assays for quantification of Shigella, Campylobacter, and Shiga-toxin producing $E$. coli were performed on 5-15 samples of water, sediment, and algae from each of 7 Great Lakes beaches. This study will provide important information about potential numbers of bacterial pathogens at different beaches; the relation between numbers of bacterial-pathogen genes and FIB concentrations; and the relative role of water, sediment, and algae as reservoirs of bacterial pathogens at beaches. Results of this study should be available in a publication in 2013 .

\section{Evaluating Sampling Methods for Pathogens}

Sampling methods for pathogens are not yet well established. Because pathogens are typically found in low numbers in environmental waters, methods are needed to concentrate pathogens from large volumes of water. It would be advantageous and cost effective to use a method that can simultaneously target all types of pathogens (viruses, bacteria, and protozoa), provided the method can reliably measure each pathogen. The USGS conducted studies that compare the reliability of different approaches to pathogen sampling.

Five filtration methods (see box) were tested for recovery of viruses and protozoa artificially added to samples, and for naturally occurring bacterial indicators in seven experiments (fig. 3).

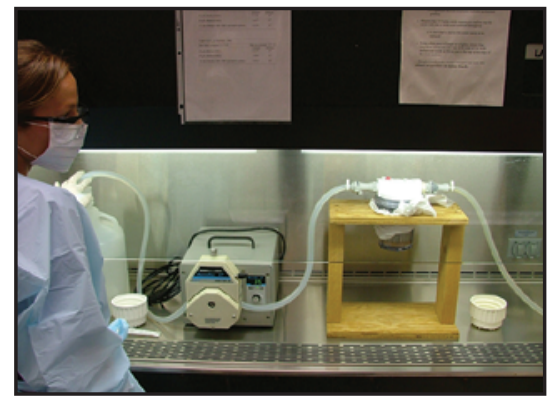

Figure 3. Filtering 10 liters of lake water in the laboratory using NanoCeram ${ }^{\odot}$ filtration. 


\section{Filtration Methods for Pathogens at Beaches}

- Glass-wool fiber filter (special order from the USGS, Marshfield, Wiscon$\sin )$

- NanoCeram ${ }^{\circledR}$ filter (Argonide, Inc., Sanford, Florida)

- Continuous flow centrifugation (CFC) with ViroCap ${ }^{\circledR}$ capsule filter (CFC+ViroCap) (Scientific Methods, Granger, Indiana)

- An automatic ultrafiltration sampler provided by the EPA, National Homeland Security Research Center (Teledyne Isco, Lincoln, Nebraska)

- Dead-end ultrafiltration

In each experiment, 10 liter lakewater samples were collected from beaches around the Great Lakes and brought back to the laboratory for artificial additions of viruses and further processing. The numbers of each type of microorganism were determined before and after filtration; the difference between these two numbers was calculated as the recovery. The variability in recovery was determined by running some of the experiments in triplicate (three runs of each filtration method instead of one).

In addition to recovery experiments, eight samples were collected during field deployment experiments at seven beaches in Ohio and Wisconsin. These experiments were done to evaluate the practicality and efficiency in using filtration for large-volume sampling at recreational beaches.

Median percent recoveries of microorganisms in lake-water samples for the five filtration methods are presented in table 1. In evaluating filter performance in terms of both recovery and variability, the automatic ultrafiltration (UF) method generally resulted in the highest recoveries while maintaining low variability for all nine microorganisms (Francy and others, 2013).
Glass-wool filtration and automatic UF were used to demonstrate that filtration can be scaled up to the collection of 200 liter lake-water samples from multiple public beaches in two States. The issue of filter clogging from high turbidity or algae was identified and reduced

Table 1. Median percent recoveries of microorganisms in seeded lake-water samples.

[CFU, colony forming units; gc, genomic copies; results from the filtration method yielding the highest recovery for each organism are shaded]

\begin{tabular}{|c|c|c|c|c|c|}
\hline & \multicolumn{5}{|c|}{ Median recoveries (percent) } \\
\hline & $\begin{array}{l}\text { Glass } \\
\text { wool }\end{array}$ & $\begin{array}{l}\text { Nano- } \\
\text { Ceram }^{\odot}\end{array}$ & $\begin{array}{c}\text { Continuous } \\
\text { flow } \\
\text { centrifugation + } \\
\text { ViroCap }\end{array}$ & $\begin{array}{l}\text { Automatic } \\
\text { ultra- } \\
\text { filtration }\end{array}$ & $\begin{array}{l}\text { Dead-end } \\
\text { ultra- } \\
\text { filtration }\end{array}$ \\
\hline Escherichia coli (CFU) & 2.1 & 0.8 & 68.3 & 64.6 & 62.1 \\
\hline Enterocooci (CFU) & .9 & .4 & 27 & 45.8 & 80.5 \\
\hline $\begin{array}{l}\text { MS2 coliphage (plaque } \\
\text { forming units) }\end{array}$ & 4.6 & 84 & 20.5 & 67.7 & 58.7 \\
\hline Adenovirus (gc) & 4.7 & .02 & .04 & 1.4 & .6 \\
\hline Norovirus GII (gc) & 2.0 & 0 & .06 & 2.4 & 2.1 \\
\hline Enterovirus (gc) & 10.5 & 14.5 & 11.3 & 3.5 & .9 \\
\hline Avian influenza virus (gc) & 0 & .007 & .002 & .01 & .02 \\
\hline Cryptosporidium (oocysts) & 10.7 & 0 & 54.0 & 35.3 & 41.0 \\
\hline Giardia (cysts) & 12.1 & 0 & 32.4 & 22.7 & 57.0 \\
\hline
\end{tabular}

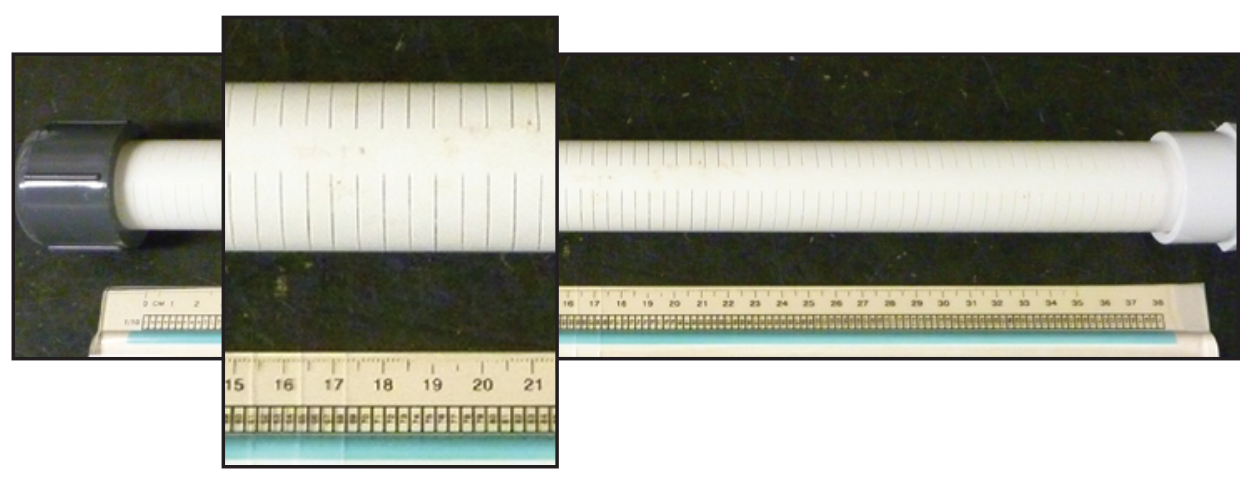

Figure 4. Field equipment used to reduce clogging of filtration systems by algae and other particles in lake-water samples. The 40-centimeter long polyvinyl chloride end connector with 0.254 millimeter slotted openings prevents particles from entering the filtration system. 


\section{Microbial Source Tracking}

Physical and biological processes at beaches can influence the occurrence and abundance of FIB and pathogens. Great Lakes beaches may vary widely in the nature of materials that form the beach, their proximity to sources of fecal pollution such as rivers, the numbers of birds or people that visit the beach, and the influence of offshore waters on the beach. However, the relations between these environmental factors and FIB concentrations or pathogen occurrence are not well understood. In recent years, DNA-based laboratory methods have been developed to distinguish between human and animal fecal contamination. These MST methods rely on the qPCR to generate copies of genes found in bacteria that tend to inhabit one host organism, such as humans or gulls. The USGS has used the qPCR/MST methods to evaluate the influence of humans, gulls, and ruminants (typically cattle or deer) on microbial contamination at Great Lakes beaches.

\section{Microbial Source Tracking Markers}

Microbial source tracking (MST) is a term used for identifying sources of fecal contamination in the environment. MST techniques are based on the concept that intestinal systems of different warmblooded animals are associated with specific microbial populations in response to differences in diet and physiology. A widely used MST method is the use of host-associated MST markers. Quantitative polymerase chain reaction (qPCR) is a laboratory method that targets, amplifies, and quantifies genetic sequences of DNA for these markers. The following qPCR MST marker assays were used by USGS researchers at beaches on inland lakes (Francy and Stelzer, 2012) and at 12 Great Lakes beaches:

- General Bacteroides marker present in most warm-blooded animals -AllBac (Layton and others, 2006)

- Human-associated Bacteroides marker-HF183 (Seurinck and others, 2005)

- Ruminant-associated Bacteroides marker-BoBac (Layton and others, 2006)
- Gull-associated marker from the species Catellicoccus marimammaliumGull2 (Sinigalliano and others, 2010)

These assays are applied as experimental methods in the emerging field of MST. Most experts agree that MST markers are one tool that should be used along with other methods to characterize fecal contamination at a site.

\section{References}

Centers for Disease Control and Prevention, 2011, Surveillance for waterborne disease outbreaks and other health events associated with recreational water-United States, 2007-2008 and surveillance for waterborne disease outbreaks associated with drinking water-United States, 2007-2008: Morbidity and Mortality Weekly Report, Surveillance Summaries, v. 60, no. $12,78 \mathrm{p}$.

Francy, D.S., and Stelzer, E.A., 2012, Microbial source tracking markers at three inland recreational lakes in Ohio, 2011: U.S. Geological Survey OpenFile Report 2012-1222, 8 p.

Francy, D.S., Stelzer, E.A., Brady, A.M.G., Huitger, Carrie, Bushon, R.N., Ip, H.S., Ware, M.W., Villegas, E.N., Gallardo, Vincente, and Lindquist, H.D.A., 2013, Comparison of filters for concentrating microbial indicators and pathogens in lake-water samples: Applied and Environmental Microbiology, v. 79, no. 4, p. 1342-1352.

Layton, Alice; McKay, Larry; Williams, Dan; Garrett, Victoria; Gentry, Randall; and Sayler, Gary, 2006, Development of Bacteroides 16S rRNA gene TaqMan-based real-time PCR assays for estimation of total, human, and bovine fecal pollution in water: Applied and Environmental Microbiology, v. 72, no. 6, p. 4214-4224.

Seurinck, Sylvie; Defoirdt, Tom; Verstraete, Willy; and Siciliano, S.D., 2005, Detection and quantification of the human-specific HF183 Bacteroides $16 \mathrm{~S}$ rRNA genetic marker with realtime PCR for assessment of human faecal pollution in freshwater: Environmental Microbiology, v. 7, no. 2, p. 249-259.
Sinigalliano, C.D.; Fleisher, J.M.; Gidley, M.L.; Solo-Gabriele, H.M.; Shibata, Tomoyuki; Plano, L.R.W.; Elmir, S.M.; Wanless, David; Bartkowiak, Jakub; Boiteau, Rene; Withum, Kelly; Abdelzaher, A.M., He, Guoqing; Ortega, Cristina; Zhu, Xiaofang; Wright, M.E.; Kish, Jonathan; Hollenbeck, Julie; Scott, Troy; Backer, L.C.; and Fleming, L.E., 2010, Traditional and molecular analyses for fecal indicator bacteria in non-point source subtropical recreational marine waters: Water Research, v. 44, no. 13, p. 3763-3772.

\section{Program Information}

Funding for USGS beach projects and research in the Great Lakes comes from a variety of sources including the Ocean Research Priority Plan, the USGS, the Great Lakes Restoration Initiative, the EPA), the NOAA Center for Great Lakes and Human Health, and many State and local partner agencies and organizations throughout the region.

\section{Contact}

James R. Morris, Director USGS Michigan and Ohio

Water Science Centers

614-430-7700

http://greatlakesbeaches.usgs.gov/ 